\title{
Perbandingan dan Sintesis Karakteristik Perilaku Perjalanan Pengguna Bis Trans Mamminasata dan Bis Trans Koetaradja
}

\author{
Comparaison and Synthese of Travel Behaviour Characteristics \\ between Trans Mamminasata Bus and Trans Koetaradja Bus Users
}

\author{
Verdy Ananda Upa ${ }^{1, \mathrm{a}}$, Hitapriya Suprayitno ${ }^{2, \mathrm{~b}}$ \& Muhammad Ryansyah ${ }^{3, \mathrm{c}}$ \\ ${ }^{1)}$ Program Studi Teknik Sipil, Institut Teknologi Indonesia (ITI), Serpong. \\ ${ }^{2)}$ Departemen Teknik Sipil, Institut Teknologi Sepuluh Nopember (ITS), Surabaya. \\ ${ }^{3)}$ Mahasiswa S1 Teknik Sipil, Institut Teknologi Sepuluh Nopember (ITS), Surabaya.

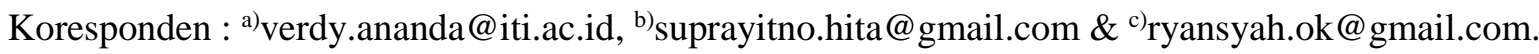

\begin{abstract}
ABSTRAK
Layanan BRT dan Semi BRT sedang banyak dikembangkan di wilayah perkotaan ibu kota Propinsi di Indonesia. Perencanaan operasional koridor baru harus disertai dengan perhitungan prakiraan jumlah penumpang. Perhitungan dilakukan dengan memakai teknik Pemodelan Transportasi. Untuk itu dibutuhkan data karakteristik perilaku perjalanan pengguna bis, untuk menentukan metoda pemodelan. Survei data karakteristik tersebut pernah dilakukan untuk Bis Trans Mamminasata dan Bis Trans Koetaradja. Kedua karakteristik tersebut ternyata cukup mirip satu dengan yang lain. Sedangkan, hasil sintesa kedua karakteristik tersebut bisa disampaikan sebagai berikut : maksud perjalanan didominasi oleh perjalanan bekerja dan kuliah, moda sebelum menggunakan Bis Trans didominasi oleh moda angkot mikrobis, perjalanan hubung ke halte didominasi oleh jarak $0-1,5 \mathrm{~km}$ dengan menggunakan moda jalan kaki dan sepeda motor, perjalanan hubung dari halte didominasi oleh jarak $0-1 \mathrm{~km}$ dengan menggunakan moda jalan kaki.
\end{abstract}

Kata Kunci : manajemen aset fasilitas, fasilitas angkutan umum kota, layanan bis kota, perilaku perjalanan, penumpang bis kota.

\section{PENDAHULUAN}

Angkutan Masal Cepat (AMC) sangat diperlukan di Indonesia bagi wilayah perkotaan ibu kota provinsi. Indonesia sedang banyak membangun AMC ini. Klas AMC yang direncanakan dan dibangun di Indonesia bervariasi dari Klas Bus Rapid Transit (BRT) - baik Semi BRT maupun BRT, Klas Light Rapid Transit (LRT) - baik Tramway, Monorail, Automated Guided Vehicle maupun Light Train dan juga Klas Mass Rapid Transit (MRT) baik Metro maupun Kereta Komuter. Jadi Perhitungan Prediksi Jumlah Penumpang bagi Trayek AMC Baru sangat penting. Untuk itu dibutuhkan Metoda Perhitungan Prediksi dan Data Karakteristik Perilaku Perjalanan Tipikal (Soimun 2018, Suprayitno \& Upa 2016, Suprayitno \& Upa 2017).

AMC sebagai Fasilitas Perkotaan harus dikelola dengan baik. Salah satu aspek Manajemen Aset Fasilitas adalah Perencanaan Operasional Fasilitas. Aspek Operasional harus direncanakan dengan baik agar Layanan Bis Kota bisa menjalankan fungsinya, sebagai Angkutan Kota Modern, dengan baik secara ekonomis, efisien dan efektif (Suprayitno \& Soemitro 2018). Dalam urusan Layanan Bis Kota, salah satu aspek Perencanaan Operasional fasilitas adalah Penentuan Jumlah Armada yang akan dioperasikan, yang harus dilakukan berdasarkan pada pada Prediksi atau Data Permintaan Jumlah Penumpang (Suprayitno \& Upa 2016; Suprayitno \& Upa 2017). 
Metoda Perhitungan Prediksi Jumlah Penumpang Angkutan Umum termasuk kedalam golongan Ilmu Pemodelan Transportasi. Pemodelan Transportasi bisa dikatagorikan menjadi 3 golongan pemodelan : Model Langsung, Model Konvensional \& Model Non Konvensional. Model Prediksi Jumlah Penumpang bagi Trayek Angkutan Baru biasa menggunakan Tipe Model Langsung atau Model Konvensional Khusus (Soimun 2018, Suprayitno 1999, Suprayitno 2005, Suprayitno 2015; Suprayitno \& Upa 2016, Suprayitno \& Upa 2017, Tamin 2008; Upa 2017).

Perhitungan Prediksi tersebut harus didasarkan pada Data Karakteristik Perjalanan pada Wilayah Studi. Untuk itu dibutuhkan Data Karakteristik Perilaku Perjalanan sebagai berikut : maksud perjalanan, penggunaan moda sebelum berpindah ke moda tinjauan, perilaku perjalanan hubung ke dan dari moda rencana, yang terutama terdiri dari data jarak perjalanan hubung dan moda perjalanan hubung (Suprayitno \& Upa 2016; Suprayitno \& Upa 2017; Upa 2017).

Penelitian mengenai Pelaku Perjalanan dan Perilaku Perjalanan berkembang sangat pesat dewasa ini. Data mengenai Karakteristik Pelaku Perjalanan dan Perilaku Perjalanan sangat dibutuhkan bagi penentuan Kebijakan, bagi Perencanaan dan bagi Perancangan Transportasi (Bamberg et al 2011; Carrey \& Perkins 2006). Contoh penelitian ini antara lain Penelitian tentang Moda Akses bagi Layanan Bis di Kota Palembang, Penelitian Perilaku Perjalanan Penumpang KA Komuter di Surabaya, serta Penelitian Kemauan Berjalan Kaki bagi penumpang bis kota di Yogyakarta (Basuki 2017; Buchari 2018, Suprayitno et al 2006).

Dua Survei Karakteristik Perilaku Perjalanan Pengguna Bis pernah dilakukan. Kedua survei dilakukan bagi Bis Trans Mamminasata - Makassar dan Bis Trans Koetaradja - Banda Aceh (Suprayitno \& Upa 2016; Suprayitno \& Ryansyah 2018). Analisis Perbandingan dan Analisis Sintesis Karateristik Perjalanan kedua hasil survei tersebut perlu untuk dilakukan . Hasil analisis ini diharapkan bisa menjadi langkah awal bagi Perumusan Karakteristik Tipikal Perjalanan dengan menggunakan AMC Klas BRT, baik untuk BRT maupun Semi-BRT.

Makalah ini menyampaikan hasil Analisis dan Sintesa Perilaku Perjalanan Penumpang Bis Kota, untuk Perjalanan Jam Puncak Pagi.

\section{METODA PENELITIAN}

Penelitian ini dilakukan dengan mengikuti urutan langkah sebagai berikut : penentuan tujuan penelitian, melakukan studi pustaka, melakukan analisis perbandingan dan sintesa karakteristik perilaku perjalanan, menyusun kesimpulan penelitian.

Data bagi Pemodelan Prediksi Penumpang Potensial dan Data Karakteristik Perilaku Perjalanan terkait disampaikan pada Tabel 1 sebagai berikut.

Tabel 1.Data bagi Pemodelan dan Data Karakteristik Terkait

\begin{tabular}{cll}
\hline No & Data bagi Pemodelan & Data Karakteristik Terkait \\
\hline 1 & Wilayah Pengaruh Ke Bis & Jarak Perjalanan Hubung Ke \\
2 & Moda Perjalanan Hubung Ke & Moda Perjalanan Hubung Ke \\
3 & Wilayah Pengaruh Dari Bis & Jarak Perjalanan Hubung Dari \\
4 & Moda Perjalanan Hubung Dari & Moda Perjalanan Hubung Dari \\
5 & Moda yang mungkin pindah & Moda Sebelum Menggunakan Bis Trans \\
6 & Kestabilan Nilai Data & Maksus Perjalanan \\
\hline sumber : Suprayitno \& Ryansyah 2018
\end{tabular}

Nilai karakteristik kuat ditentukan oleh komponen karakteristik dengan nilai komulatif lebih dari $75 \%$. 


\section{STUDI PUSTAKA}

\section{Karakteristik Pelaku dan Perilaku Perjalanan Komuter Penumpang KA di Surabaya}

Suatu penelitian tentang Karakteristik Pelaku dan Perilaku Perjalanan Penumpang Komuter Kereta Api (KA) di Wilayah Gerbangkertosusila telah dilakukan. Layanana KA yang disurvei adalah : KA Komuter Susi, KA Penataran, KA Rapih Dhoho, KRD Kertosono, KRD Bojonegoro, KRD Cepu. Survei ini dilakukan pada awal tahun 2006, pada Hari Kerja pada Jam Perjalanan Pagi. Jumlah sample diambil adalah 1.444 orang, dari jumlah penumpang sebanyak 10.378 orang (Suprayitno et al 2006).

- Karakterisitk utama Pelaku Perjalanan adalah sebagai berikut : umur didominasi oleh umur 21-40 tahun (61,77\%), pendidikan didominasi oleh lulusan SMU (44,31\%), pekerjaan didominasi oleh pegawai swasta $(33,45 \%)$, sedangkan jenis kelamin didominasi oleh laki2 $(66,90 \%)$.

- Karakteristik utama Perilaku Perjalanan adalah sebagai berikut : maksud perjalanan didominasi oleh perjalanan bekerja $(41,20 \%)$, guna lahan asal didominasi oleh rumah $(84,63 \%)$, guna lahan tujuan terbesar adalah rumah $(34,42 \%)$, moda hubung ke sebanyak 2 kali sebesar $0,76 \%$, moda hubung ke yang menempel ke KA didominasi oleh sepeda motor $(30,89 \%)$, jalan kaki $(29,79 \%)$ dan mikrobis $(26,45 \%)$, moda hubung dari sebanyak 2 kali sebesar 1,87\%, moda hubung dari yang menempel ke KA didominasi oleh mikrobis $(42,27 \%)$ dan jalan kaki $(37,67 \%)$, frekwensi menggunakan KA sebanyak 6x adalah : 20,15\%, sedangkan sebanyak 1x adalah $18,42 \%$, moda yang digunakan setahun lalu adalah bis $(27,15 \%)$, mikrobis $(23,61 \%)$, KA $(19,46 \%)$ dan sepeda motor $(12,47 \%)$.

\section{Wilayah Pengaruh Layanan Angkutan Bertrayek}

Survei Identifikasi Awal tentang Wilayah Pengaruh Layanan KA Komuter di Surabaya, KA Komuter Susi \& KA Komuter Sulam, pernah dilakukan, pada Akhir Tahun 2017. Survei dilakukan dalam Hari Kerja, pada Jam Puncak Pagi (Susanti, Soemitro \& Suprayitno 2018; Susanti, Soemitro \& Suprayitno 2017, Susanti, Soemitro \& Suprayitno 2017a, Susanti, Soemitro \& Suprayitno 2017b). Hasil utama identifikasi awal ini adalah sebagai berikut.

- Wilayah Pengaruh bagi moda Jalan Kaki bagi Perjalanan Hubung Ke adalah 500 m, sedangkan bagi Perjalanan Hubung Dari adalah $400 \mathrm{~m}$.

- Wilayah Pengaruh bagi moda Angkutan Umum bagi Perjalanan Hubung Ke adalah 9000 m, sedangkan bagi Perjalanan Hubung Dari adalah dari 6000 m.

- Wilayah Pengaruh bagi moda Sepeda Motor bagi Perjalanan Hubung Ke adalah 11000 m, sedangkan bagi Perjalanan Hubung Dari adalah 7500 m.

- Wilayah Pengaruh bagi moda Mobil adalah sebagai berikut. Wilayah Pengaruh bagi KA Susi arah Sidoarjo-Surabaya adalah : bagi Perjalanan Hubung Ke adalah $4600 \mathrm{~m}$ dan bagi Perjalanan Hubung Dari adalah $4100 \mathrm{~m}$. Sedangkan Wilayah Pengaruh bagi KA

Sulam arah Surabaya-Lamongan adalah : bagi Perjalanan Hubung Ke adalah 4000 km dan bagi Perjalanan Hubung Dari adalah 23000 km.

Sebuah penelitian tentang Kemauan Untuk Berjalan Kaki (Willingness to Walk) telah dilakukan bagi Penumpang Bis Kota di Yogyakarta. Penelitian ini menghasilkan Jarak yang sama, baik bagi Penumpang Mikrobis maupun bagi Penumpang Trans Jogja, sebesar $150 \mathrm{~m}$ (Basuki 2017).

\section{Karakteristik Intermoda Angkutan Umum}

Karakteristik Intermoda Angkutan Umum di Kota Palembang pernah diteliti pada tahun 2011. Penelitian ini terutama melihat Moda bagi Perjalanan Hubung Ke untuk Angkutan 
Umum Oplet dan Bis Trans Musi. Moda Perjalanan Hubung Ke bagi Oplet didominasi oleh Moda Jalan Kaki $(79,7 \%)$ dan Becak $(14,7 \%)$. Moda Perjalanan Ke bagi Bis Trans Musi didominasi oleh Moda Jalan Kaki (45.3\%), Ojek (26\%) dan Becak (13,3\%) (Buchari 2018).

\section{ANALISIS PERBANDINGAN DAN SINTESA}

\section{Komponen Perbandingan Karakteristik}

Data Karakteristik Perilaku Perjalanan yang dibandingkan adalah data gabungan Bis Trans Mamminasata, Makassar : Koridor 2 : Mall Panakukang - Mall GTC dan Koridor 3 : Simpang Bandara - Terminal Palangga, terhadap Bis Trans Koetaradja, Banda Aceh : Koridor 1 : Keudah - Darulsalam. Peta Rute Trans Mamminasata Koridor 2 dan Koridor 3 disampaikan pada Gambar 1, sedangkan Peta Rute Trans Koetaradja Koridor 1 disampaikan pada Gambar 2 dibawah ini (Suprayitno \& Ryansyah 2018; Suprayitno \& Upa 2016).

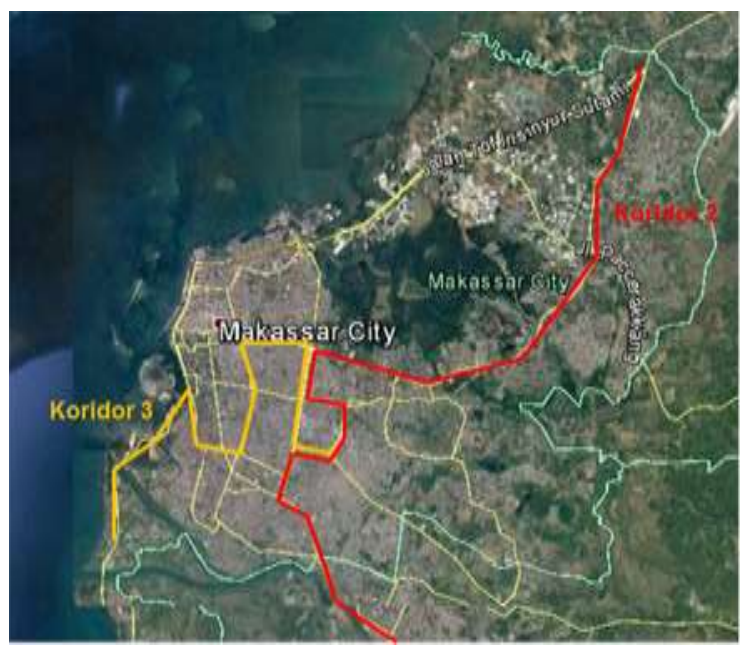

Gambar 1. Trans Mamminsata Koridor 2 dan Koridor 3

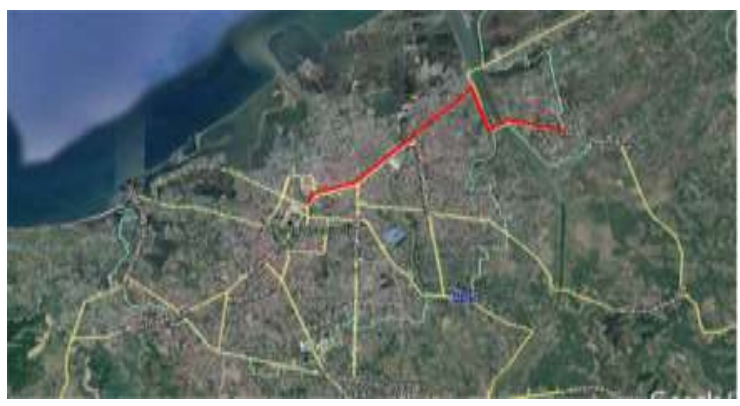

Gambar 2. Trans Koetaradja Koridor 1 : Kedah - Darulsalam

Hasil penelitian ini ditujukan untuk dipakai dalam Pemodelan Transportasi untuk memprediksi Jumlah Permintaan Penumpang. Oleh karena itu Data Karakteritik Perilaku Perjalanan yang harus diketahui adalah : maksud perjalanan, penggunaan moda sebelum terbiasa menggunakan moda tinjauan, perilaku perjalanan hubung ke : jarak dan moda, serta perjalanan hubung dari : jarak dan moda. Kedua Data Karakteristik adalah data Jam Puncak Pagi.

\section{Karakteristik Perilaku Perjalanan Pengguna Bis Trans Mamminasata}

Karakteristik tentang Maksud Perjalanan dan Moda sebelum berpindah bisa disampaikan sebagai berikut. Survei menunjukkan bahwa Layanan Bis pada Jampuncak Pagi terisi oleh Perjalanan Bekerja sebanyak 50\% dan Perjalanan Sekolah sebanyak 50\%. 
Penggunaan Moda Sebelum Pindah didominasi oleh Moda Angkot sebesar 76\% dan oleh Moda Sepeda Motor sebesar 24\%. Karakteristik ini dipresentasikan pada Tabel 2 dan Tabel 3 dibawah ini.

Table 2. Karakteristik Maksud Perjalanana Pengguna Bis - Trans Mamminasata

\begin{tabular}{cccccc}
\hline No & Maksud & Kor $\mathbf{1}$ & Kor 2 & Total & Prosentase \\
\hline 1 & Bekerja & 17 & 23 & 40 & $50 \%$ \\
2 & Sekolah & 23 & 17 & 40 & $50 \%$ \\
\hline \multicolumn{2}{l}{ Total } & 40 & 40 & 80 & $100 \%$ \\
\hline
\end{tabular}

sumber : Suprayitno \& Upa 2016

Tabel 3. Karakteritik Penggunaan Moda sebelum beralih ke Bis - Trans Mamminasata

\begin{tabular}{cccccc}
\hline No & Moda & Kor 2 & Kor 3 & Total & Prosentase \\
\hline 1 & Angkot & 29 & 32 & 61 & $76 \%$ \\
2 & Sepeda Motor & 11 & 8 & 19 & $24 \%$ \\
3 & Mobil & 0 & 0 & 0 & $0 \%$ \\
\hline & Total & 40 & 40 & 80 & $100 \%$ \\
\hline
\end{tabular}

sumber : Suprayitno \& Upa 2016

Karakteristik Perilaku Perjalanan Hubung Ke dan Perjalanan Hubung Dari unutk Trans Mamminasata adalah sebagai berikut. Secara umum Jarak Perjalanan Hubung Ke $(0-2 \mathrm{~km})$ lebih panjang dari pada Jarak Perjalanan Hubung Dari $(0-0,5 \mathrm{~km})$. Moda Perjalanan Hubung Ke didominasi oleh Sepeda Motor (51\%) dan Angkutan Umum (19\%). Moda Perjalanan Hubung Dari didominasi oleh Jalan Kaki (71\%) dan Becak (18\%). Data tentang Perjalanan Hubung disampaikan pada Tabel 4 sampai dengan Tabel 7 sebagai berikut.

Tabel 4. Karakteristik Jarak Perjalanan Hubung Ke Bis - Trans Mamminasata

\begin{tabular}{clcccc}
\hline No & Jarak & Kor $\mathbf{1}$ & Kor 2 & Total & Prosentase \\
\hline 1 & $0.0-1.0 \mathrm{~km}$ & 12 & 17 & 29 & $36 \%$ \\
2 & $1.0-2.0 \mathrm{~km}$ & 20 & 18 & 38 & $48 \%$ \\
3 & $2.0-3.0 \mathrm{~km}$ & 8 & 5 & 13 & $16 \%$ \\
\hline & Total & 40 & 40 & 80 & $100 \%$ \\
\hline
\end{tabular}

sumber : Suprayitno \& Upa 2016

Tabel 5. Karakteristik Moda Perjalanan Hubung Ke Bis - Trans Mamminasata

\begin{tabular}{cccccc}
\hline No & Moda & Kor 2 & Kor 3 & Total & Prosentase \\
\hline 1 & Jalan Kaki & 3 & 4 & 7 & $8 \%$ \\
2 & Becak & 1 & 13 & 14 & $18 \%$ \\
3 & Angkot & 12 & 3 & 15 & $19 \%$ \\
4 & Sepeda Motor & 21 & 20 & 41 & $51 \%$ \\
5 & Mobil & 3 & 0 & 3 & $4 \%$ \\
\hline & Total & 40 & 40 & 80 & $100 \%$ \\
\hline
\end{tabular}

sumber : Suprayitno \& Upa 2016

Tabel 6. Karakteristik Jarak Perjalanan Hubung Dari Bis - Trans Mamminasata 


\begin{tabular}{cccccc}
\hline No & Jarak & Kor 2 & Kor 3 & Total & Prosentase \\
\hline 1 & $0.0-0.5 \mathrm{~km}$ & 29 & 28 & 57 & $71 \%$ \\
2 & $0.5-1.0 \mathrm{~km}$ & 11 & 6 & 17 & $21 \%$ \\
3 & $1.0-1.5 \mathrm{~km}$ & 0 & 6 & 6 & $8 \%$ \\
\hline & Total & 40 & 40 & 80 & $100 \%$ \\
\hline
\end{tabular}

sumber : Suprayitno \& Upa 2016

Tabel 7. Karakteristik Moda Perjalanan Hubung Dari Bis - Trans Mamminasata

\begin{tabular}{cccccc}
\hline No & Moda & Kor 2 & Kor 3 & Total & Prosentase \\
\hline 1 & Jalan Kaki & 29 & 28 & 57 & $71 \%$ \\
2 & Becak & 11 & 3 & 14 & $18 \%$ \\
3 & Angkot & 0 & 9 & 9 & $11 \%$ \\
\hline & Total & 40 & 40 & 80 & $100 \%$ \\
\hline
\end{tabular}

sumber : Suprayitno \& Upa 2016

\section{Karakteristik Perilaku Perjalanan Pengguna Bis Trans Koetaradja}

Survei menemukan bahwa pola Volume Penggunaan Bis Trans Koetaradja Koridor 1 : Keudah-Darussalam tidak umum, Volume Penumpang pada Jam Puncak Pagi sangat sedikit dibandingkan pada Jam Siang Hari. Maksud Perjalanan untuk Jam Puncak Pagi didominasi oleh maksud Bekerja sebesar 55\% dan maksud Belanja sebesar 25\%. Moda Sebelum Pindah ke Moda Utama didominasi oleh Angkot sebesar 80\%. Data Karakteristik Perilaku Perjalanan disampaikan pada Tabel 8 dan Tabel 9 sebagai berikut.

Tabel 8. Karakteristik Maksud Perjalanan - Trans Koetaradja

\begin{tabular}{cccc}
\hline No & Maksud & Jumlah & Prosentase \\
\hline 1 & Bekerja & 11 & $55 \%$ \\
2 & Belanja & 5 & $25 \%$ \\
3 & Kuliah & 4 & $20 \%$ \\
\hline & Total & 20 & $100 \%$ \\
\hline
\end{tabular}

sumber : Suprayitno \& Ryuansyah 2018

Tabel 9. Karakteristik Penggunaan Moda sebelum beralih ke Bis - Trans Koetaradja

\begin{tabular}{cccc}
\hline No & Moda & Jumlah & Prosentase \\
\hline 1 & Angkot & 16 & $80 \%$ \\
2 & Sepeda Motor & 4 & $20 \%$ \\
3 & Mobil & 0 & $0 \%$ \\
\hline & Total & 20 & $100 \%$ \\
\hline
\end{tabular}

sumber : Suprayitno \& Ryansyah 2018

Karakteristik Perilaku Perjalanan Hubung Ke dan Perjalanan Hubung Dari adalah sebagai berikut. Jarak Perjalanan Hubung Ke sampai sejauh $1.5 \mathrm{~km}$, sedangkan Jarak Perjalanan Dari lebih pendek, sampai sejauh $1 \mathrm{~km}$. Moda Perjalanan Hubung Ke didominasi oleh Jalan Kaki sebesar 90\%, sedangkan Moda Perjalanan Hubung Dari didominasi oleh Jalan Kaki sebesar $100 \%$. Data Perjalanan Hubung disampaikan pada Tabel 10 sampai dengan Tabel 13 sebagai berikut. 
Tabel 10. Karakteristik Jarak Perjalanan Hubung Ke Bis - Trans Koetaradja

\begin{tabular}{cccc}
\hline No & Jarak & Jumlah & Prosentase \\
\hline 1 & $0.0-0.5 \mathrm{~km}$ & 8 & $40 \%$ \\
2 & $0.5-1.0 \mathrm{~km}$ & 7 & $35 \%$ \\
3 & $1.0-1.5 \mathrm{~km}$ & 3 & $15 \%$ \\
4 & $1.5-2.0 \mathrm{~km}$ & 1 & $5 \%$ \\
5 & $2.0-3.0 \mathrm{~km}$ & 1 & $5 \%$ \\
\hline & Total & 20 & $100 \%$ \\
\hline
\end{tabular}

sumber : Suprayitno \& Ryansyah 2018

Tabel 11. Karakteristik Moda Perjalanan Hubung Ke Bis - Trans Koetaradja

\begin{tabular}{cccc}
\hline No & Moda & Jumlah & Prosentase \\
\hline 1 & Jalan Kaki & 18 & $90 \%$ \\
2 & Angkot & 1 & $5 \%$ \\
3 & Sepeda Motor & 1 & $5 \%$ \\
4 & Mobil & 0 & $0 \%$ \\
\hline & Total & 20 & $100 \%$ \\
\hline
\end{tabular}

sumber : Suprayitno \& Ryansyah 2018

Tabel 12. Karakteristik Jarak Perjalanan Hubung Dari Bis - Trans Koetaradja

\begin{tabular}{cccc}
\hline No & Jarak & Jumlah & Prosentase \\
\hline 1 & $0.0-0.5 \mathrm{~km}$ & 13 & $65 \%$ \\
2 & $0.5-1.0 \mathrm{~km}$ & 6 & $30 \%$ \\
3 & $1.0-1.5 \mathrm{~km}$ & 1 & $5 \%$ \\
4 & $1.5-2.0 \mathrm{~km}$ & 0 & $0 \%$ \\
5 & $2.0-3.0 \mathrm{~km}$ & 0 & $0 \%$ \\
\hline & Total & 20 & $100 \%$
\end{tabular}

sumber : Suprayitno \& Ryansyah 2018

Tabel 13. Karakteristik Moda Perjalanan Hubung Dari Bis - Trans Koetaradja

\begin{tabular}{cccc}
\hline No & Moda & Jumlah & Prosentase \\
\hline 1 & Jalan Kaki & 20 & $100 \%$ \\
2 & Angkot & 0 & $0 \%$ \\
3 & Sepeda Motor & 0 & $0 \%$ \\
4 & Mobil & 0 & $0 \%$ \\
\hline & Total & 20 & $100 \%$ \\
\hline
\end{tabular}

sumber : Suprayitno \& Ryansyah 2018

\section{Analisis Perbandingan dan Sintesa}

Secara umum, Karakteristik Perilaku Perjalanan pengguna kedua Semi-BRT tersebut sangat mirip. Hal ini bisa diceritakan sebagai berikut. Maksud Perjalanan keduanya didominasi oleh Perjalanan Bekerja dan Perjalanan Sekolah. Penggunaan Moda Sebelum Berpindah sangat mirip, didominasi terutama oleh Moda Angkota Bis Mikro (78\%) dan juga oleh moda Sepeda Motor (22\%). Karakteritik Perjalanan Perjalanan Hubung Ke, bagi aspek Jarak Trans Koet didominanasi oleh jarak 0-1 km, bagi Trans Mamminasata didominasi oleh 
jarak 1-2 km, sedangkan bagi aspek Moda, Bis Trans Koetaradja didominasi oleh Jalan Kaki, Bis Trans Mamminasata disominasi oleh Sepeda Motor dan Angkot Tradisional. Kedua Perjalanan Hubung Dari dalam aspek Jarak dan Moda sangat mirip.

Karena Karakteristik Perilaku Pejalanan bagi kedua Bis Trans tersebut sangat mirip, maka Data Perilaku Perjalanan bisa disintesakan sebagai berikut.

Sintesa Karakteristik Perilaku Perjalanan bisa disampaikan sebagai berikut. Maksud Perjalanan didominasi oleh maksud Bekerja dan Kuliah, pada angka komulatif 87,5\%. Penggunaan Moda Sebelum Beralih didominasi oleh Angkot Tradisional (78\%) dan Sepeda Motor (22\%). Hasil perhitungan sintesa disampaikan pada Tabel 14, Tabel 15, Gambar 3 dan Gambar 4 sebagai berikut.

Table 14. Karakteristik Maksud Perjalanan - Sintesa

\begin{tabular}{cccccc}
\hline No & Maks ud & Trans Koet & Trans Mammi & Sintesa & Komulatif \\
\hline 1 & Bekerja & $55 \%$ & $50 \%$ & $52.5 \%$ & $52.5 \%$ \\
2 & Kuliah & $20 \%$ & $50 \%$ & $35.0 \%$ & $87.5 \%$ \\
3 & Belanja & $25 \%$ & $0 \%$ & $12.5 \%$ & $100.0 \%$ \\
\hline & Total & $100 \%$ & $100 \%$ & $100.0 \%$ & \\
\hline
\end{tabular}

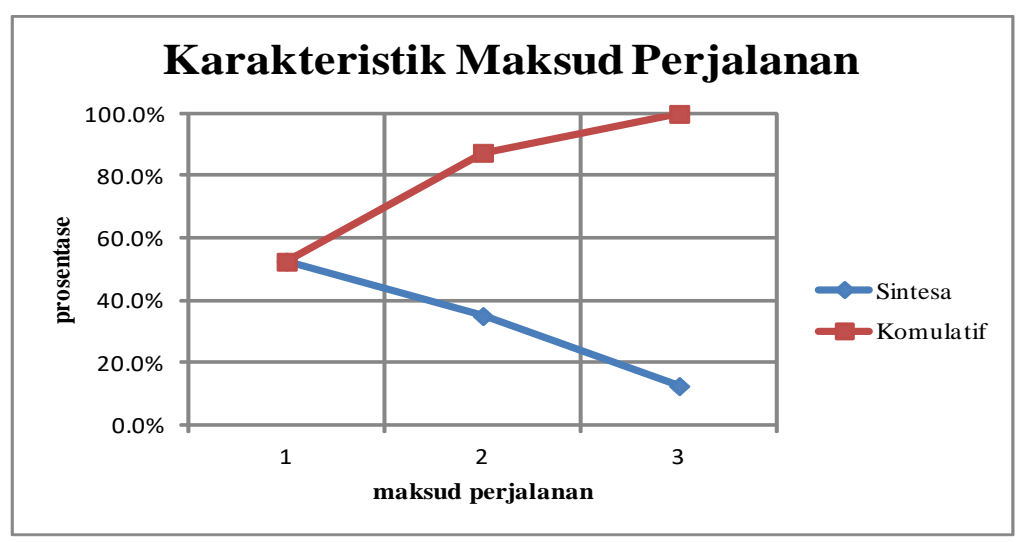

Gambar 3. Karakteristik Maksud Perjalanan - Sintesa

Tabel 15. Karakteristik Penggunaan Moda sebelum beralih - Sintesa

\begin{tabular}{cccccc}
\hline No & Moda & Trans Koet & Trans Mammi & Sintesa & Komulatif \\
\hline 1 & Angkot & $80 \%$ & $76 \%$ & $78 \%$ & $78 \%$ \\
2 & Sepeda Motor & $20 \%$ & $24 \%$ & $22 \%$ & $100 \%$ \\
3 & Mobil & $0 \%$ & $0 \%$ & $0 \%$ & $100 \%$ \\
\hline & Total & $100 \%$ & $100 \%$ & $100 \%$ & \\
\hline
\end{tabular}




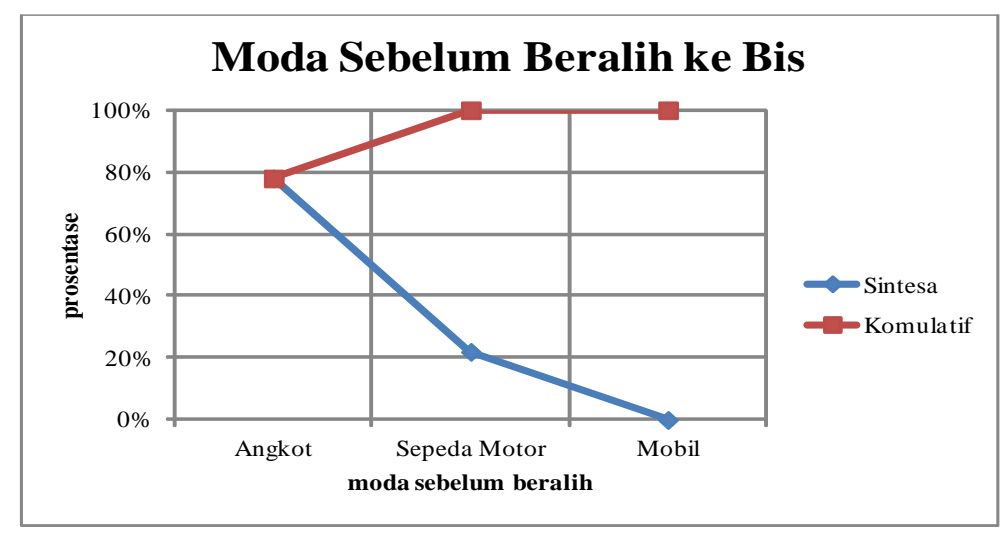

Gambar 4. Moda Sebelum Beralih Ke Bis

Karakteristik Perilaku Perjalan Hubung Ke dan Perjalanan Hubung Dari bisa disintesakan sebagai berikut. Perjalanan Hubung Ke Halte Bis aspek Jarak didominasi oleh nilai $0-1,5 \mathrm{~km}$ pada angka komulatif $75 \%$, sedangkan aspek Moda didominasi oleh Jalan Kaki (49\%) dan Sepeda Motor (28\%) total pada angka komulatif $77 \%$. Perjalanan Hubung Dari Halte Bis aspek Jarak didominasi oleh nilai 0 - $1 \mathrm{~km}$ pada angka komulatif 93,5\%, sedangkan aspek Moda didominasi oleh Jalan Kaki pada angka komulatif 85,5\%. Perhitungan dan Gambar Sintesa Karakteristik Perjalanan Hubung disampaikan pada Tabel 16 sampai dengan Tabel 19, serta Gambar 3 dan Gambar 4 sebagai berikut.

Tabel 16. Karakteristik Jarak Perjalanan Hubung Ke Bis - Sintesa

\begin{tabular}{cccccc}
\hline No & Jarak & Trans Koet & Trans Mammi & Sintesa & Komulatif \\
\hline 1 & $0.0-0.5$ & $40 \%$ & $18 \%$ & $29.0 \%$ & $29.0 \%$ \\
2 & $0.5-1.0$ & $35 \%$ & $18 \%$ & $26.5 \%$ & $55.5 \%$ \\
3 & $1.0-1.5$ & $15 \%$ & $24 \%$ & $19.5 \%$ & $75.0 \%$ \\
4 & $1.5-2.0$ & $5 \%$ & $24 \%$ & $14.5 \%$ & $89.5 \%$ \\
5 & $2.0-3.0$ & $5 \%$ & $16 \%$ & $10.5 \%$ & $100.0 \%$ \\
\hline \multicolumn{7}{r}{ Total } & $100 \%$ & $100 \%$ & $100.0 \%$ & \\
\hline
\end{tabular}

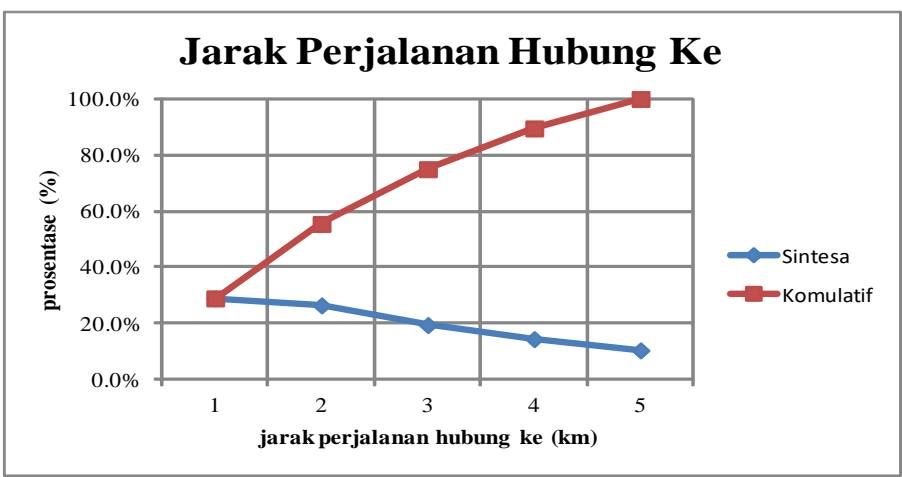

Gambar 5. Nilai Prosentase Jarak - Perjalanan Hubung Ke 
Tabel 17. Karakteristik Moda Perjalanan Hubung Ke Bis - Sintesa

\begin{tabular}{cccccc}
\hline No & Moda & Trans Koet & Trans Mammi & Sintesa & Komulatif \\
\hline 1 & Jalan Kaki & $90 \%$ & $8 \%$ & $49 \%$ & $49 \%$ \\
2 & Sepeda Motor & $5 \%$ & $51 \%$ & $28 \%$ & $77 \%$ \\
3 & Angkot & $5 \%$ & $19 \%$ & $12 \%$ & $89 \%$ \\
4 & Becak & $0 \%$ & $18 \%$ & $9 \%$ & $98 \%$ \\
5 & Mobil & $0 \%$ & $4 \%$ & $2 \%$ & $100 \%$ \\
\hline & Total & $100 \%$ & $100 \%$ & $100 \%$ & \\
\hline
\end{tabular}

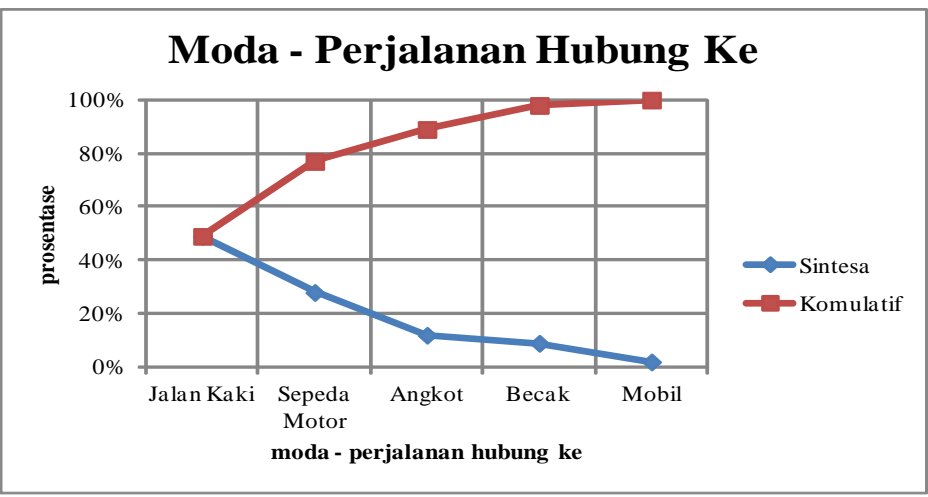

Gambar 6. Moda - Perjalanan Hubung Ke

Tabel 18. Karakteristik Jarak Perjalanan Hubung Dari Bis - Sintesa

\begin{tabular}{cccccc}
\hline No & Jarak & Trans Koet & Trans Mammi & Sintesa & Komulatif \\
\hline 1 & $0.0-0.5$ & $65 \%$ & $71 \%$ & $68.0 \%$ & $68.0 \%$ \\
2 & $0.5-1.0$ & $30 \%$ & $21 \%$ & $25.5 \%$ & $93.5 \%$ \\
3 & $1.0-1.5$ & $5 \%$ & $8 \%$ & $6.5 \%$ & $100.0 \%$ \\
\hline \multicolumn{2}{l}{ Total } & $100 \%$ & $100 \%$ & $100.0 \%$ & \\
\hline
\end{tabular}

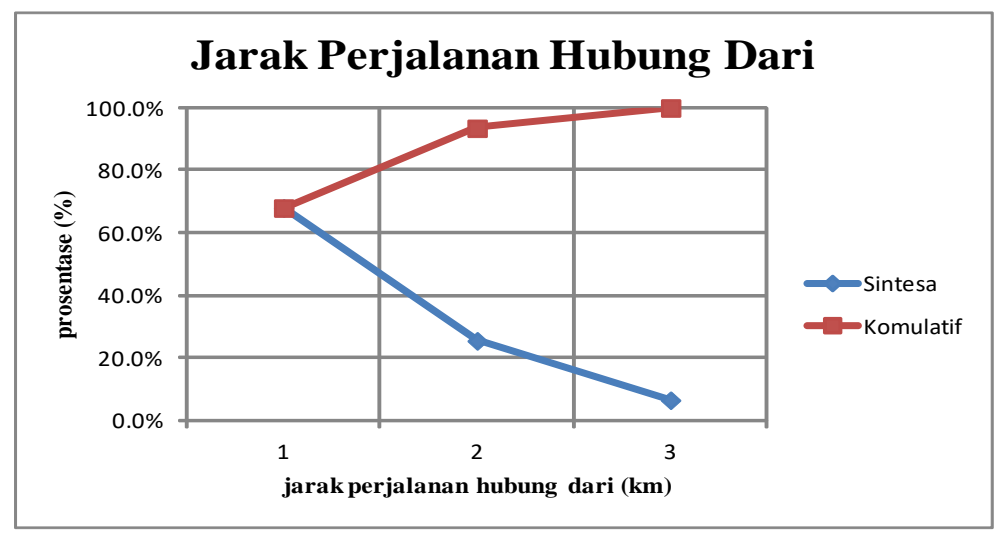

Gambar 7. Nilai Prosentase Jarak - Perjalanan Hubung Dari

Tabel 19. Karakteristik Moda Perjalanan Hubung Dari Bis - Sintesa

\begin{tabular}{cccccc}
\hline No & Moda & Trans Koet & Trans Mammi & Sintesa & Komulatif \\
\hline 1 & Jalan Kaki & $100 \%$ & $71 \%$ & $85.5 \%$ & $85.5 \%$ \\
2 & Becak & $0 \%$ & $18 \%$ & $9.0 \%$ & $94.5 \%$ \\
3 & Angkot & $0 \%$ & $11 \%$ & $5.5 \%$ & $100.0 \%$ \\
4 & Sepeda Motor & $0 \%$ & $0 \%$ & $0.0 \%$ & $100.0 \%$ \\
\hline & Total & $100 \%$ & $100 \%$ & $100 \%$ & \\
\hline
\end{tabular}




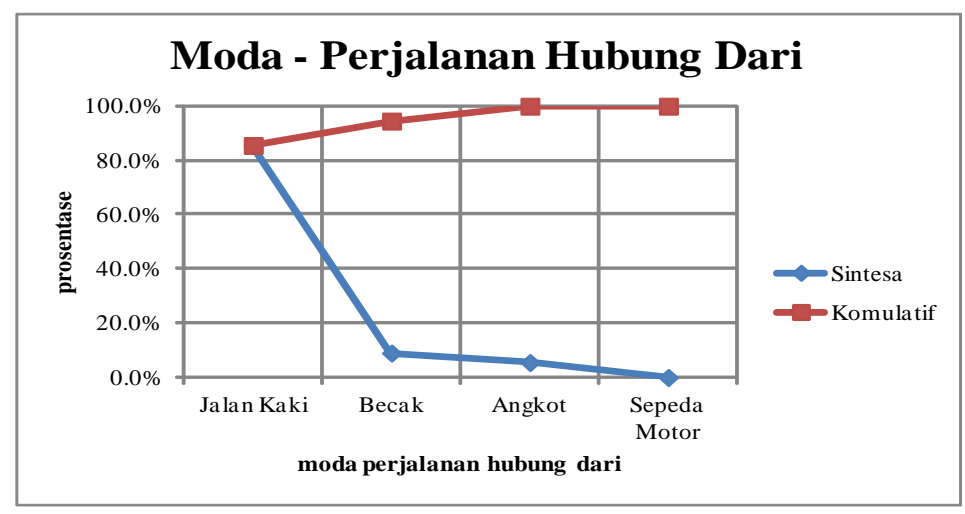

Gambar 8. Moda Perjalanan Hubung Dari

\section{KESIMPULAN}

Pada akhirnya, penelitian ini telah mampu menghasilkan beberapa kesimpulan utama tentang Analisis Perbandingan dan Analisis Sintesa Perilaku Perjalanan Pengguna Bis.

- Secara umum Karakteristik Perilaku Perjalanan pengguna Bis Trans Mamminasata mirip dengan Perilaku Perjalanan pengguna bis Trans Koetaradja. Karakteristik kedua Layanan Bis tersebut juga cukup sesuai dengan penelitian mengenai Perilaku Perjalanan KA Komuter dan Karakterisitk Intermoda Angkutan Kota di Palembang.

Oleh karana itu analisis penelitian ini bisa diteruskan kearah Analisis Sintesa Karakteristik Perilaku Perjalanan. Karakteristik ini bisa mulai dianggap sebagai Karakteristik Tipikal, walaupun sebaiknya lebih dikembangkan dengan menambah data lain dari koridor lain. Hasil Analisis Sintesa Karakteristik disampaikan sebagai berikut.

- Maksud Perjalanan didominasi oleh maksud Bekerja dan Kuliah, pada angka komulatif $87,5 \%$.

- Penggunaan Moda Sebelum Beralih didominasi oleh moda Angkot Tradisional (78\%) dan oleh Sepeda Motor (22\%)..

- Perjalanan Hubung Ke Halte Bis : tentang aspek Jarak didominasi oleh nilai 0-1,5 km, pada angka komulatif 75\%, sedangkan aspek Moda didominasi oleh Jalan Kaki dan Sepeda Motor, pada angka komulatif $77 \%$.

- Perjalanan Hubung Dari Halte Bis : tentang aspek Jarak didominasi oleh nilai $0-1 \mathrm{~km}$, pada angka komulatif 93,5\%, sedangkan aspek Moda didominasi oleh Jalan Kaki, pada angka komulatif $85,5 \%$.

Data Sintesa ini bisa digunakan sebagai Acuan Terbatas bagi Karakteristik Tipikal Perilaku Perjalanan Pengguna Semi BRT dan sebagai Acuan Pembanding bagi analisis yang lain.

Penelitian ini bisa dikembangkan kearah penyusunan karakteristik tipikal perilaku perjalanan pengguna BRT dengan menambah data survei karakteristik bagi koridor yang lain, kearah melengkapi karakteristik tipikal dengan menambah data tentang panjang perjalanan bis dan data pelaku perjalanan, serta kearah penyusunan Karakteristik Tipikal Pelaku dan Perilaku Perjalanan untuk Tipe AMC yang lain.

Catatan. Data Karakteristik Perilaku Perjalanan Bis Trans Koetaradja dikumpulkan oleh Muhammad Riansyah untuk Tugas Akhir. Data tentang Trans Mamminasata dikumpulkan oleh Verdy Ananda Upa untuk Tesis. 


\section{DAFTAR PUSTAKA}

Bamberg, S., Fujii, S., Friman, M. \& Garling, T. (2011). "Travel Behaviour and Soft Transport Policy Measures". Transport Policy 18, pp. 228 - 235.

Basuki, Imam (2017). "The Willingness to Walk of Urban Transportation Passengers ( A Case Study of Urban Transportation Passengers in Yogyakarta Indonesia)". JTSS Journal of Technology and Social Science, Vol. 1, No. 2, July 2017, pp : 19-26.

Buchari, Erika (2018)."Hierarchical Service for Integrating Multimodal Public Transport System in Palembang, Indonesia". JTSS - Journal of Technology and Social Science, Vol. 2, No. 1, July 2017, pp : 19-26.

Curtis, Carrey \& Perkins, Tim (2006). "Working Paper No. 3 : Travel Behaviour”. Urbanet. Department of Urban and Regional Planning. Curtin University.

Soimun, Ahmad (2018). "Analisis Probabilitas Perpindahan Moda Pengguna Kendaraan Pribadi (Sepeda Motor dan Mobil) ke Kereta Api Commuter Surabaya Sidoarjo". Tesis Magister. Departemen Teknik Sipil. Institut Teknologi Sepuluh Nopember (ITS). Surabaya.

Suprayitno, Hitapriya (1999). "Metoda Pemodelan Kebutuhan Angkutan Barang Perkotaan Kasus Kota Surabaya". Prosiding Simposium FSTPT 2, Desember 1999. Surabaya.

Suprayitno, Hitapriya (2005). "Pengembangan Awal Metoda Perhitungan PADI 0.0 Model Sebaran Perjalanan Berbasis Data Arus Lalu Lintas". Jurnal Teknobisnis, Vol. 1, No. 2, Tahun 2006, hal. 167-174.

Suprayitno, H., Irlambang, D., Pramono, Y.A. \& Wibowo, A.G. (2006). "Karakteristik Penumpang dan Perjalananan pada KA Penumpang Ekonomi di Wilayah Gerbangkertosusila". Jurnal Teknobisnis, Vol. 2, No. 1, Tahun 2006, hal : 41-48.

Suprayitno, Hitapriya (2015). "Penyusunan Metoda Perhitungan Model Distribusi Perjalanan Berbasis Data Volume Lalu Lintas pada Kasus Pembebanan All-or-Nothing". ATPW 2015, Seminar Nasional Aplikasi Teknik Prasarana Wilayah 2015. Surabaya.

Suprayitno, Hitapriya \& Upa, Verdy Ananda (2017). "Mamminasata BRT User Trip Characteristics for the Design of Demand Modelling Method for a New BRT Line". IPTEK, The Journal for Technology and Science, Vol. 27, Issue. 3, December 2016, pp : 47-52.

Suprayitno, Hitapriya \& Upa, Verdy Ananda (2017). "Special Conventional Transport Model for a New BRT Line Passenger Demand Prediction”. JTSS - Journal of Technology and Social Science, Vol. 1, Issue 3, 2017, pp : 10-18.

Suprayitno, H. \& Ryansyah, M. (2018). "Karakteristik Pelaku dan Perilaku Perjalanan Penumpang Bis Trans Koetaradja, Koridor 1 : Keudah - Darulsalam”. Diaju-serahkan pada Jurnal Aplikasi Teknik Sipil, Mei 2018.

Suprayitno, H \& Soemitro, R.A.A. (2018). "Preliminary Reflexion on Basic Principle of Infrastructure Asset Management". Jurnal Manajemen Aset Infrastruktur \& Fasilitas, Vol. 2, No. 1, Maret 2018.

Susanti, A., Soemitro, R.A.A. \& Suprayitno, H. (2018). "Identifikasi Awal Wilayah Pengaruh KA Komuter Ditinjau dari Penggunaan Mobil di Kota Surabaya”. Bangunan, Vol. 23, No. 1, Tahun 2018.

Susanti, A., Soemitro, R.A.A. \& Suprayitno, H. (2017). "Wilayah Pengaruh Kereta Api Komuter terhadap Pengguna Sepeda Motor di Kota Surabaya". Jurnal Transportasi, Vol. 17, No. 3, Tahun 2017.

Susanti, A., Soemitro, R.A.A. \& Suprayitno, H. (2017a). "Wilayah Pengaruh KA Komuter ditinjau terhadap Jalan Kaki”. Dikumpulkan bagi Seminar FSTPT Tengah Tahun 2017 di Semarang. 
Susanti, A., Soemitro, R.A.A. \& Suprayitno, H. (2017b). "Identifikasi Awal Wilayah Pengaruh KA Komuter dengan menggunakan Angkutan Umum Pengumpan". Rekayasa Sipil, Vol. 11, No. 3, Tahun 2017.

Tamin, O.Z. (2008). Perencanaan, Pemodelan \& Rekayasa Transportasi : Teori, Contoh Soal \& Aplikasi. Penerbit ITB. Bandung.

Upa, Verdy Ananda \& Suprayitno, H. (2016). “Analisis Hubungan Antara Jumlah Naik dan Turun Penumpang dengan Tata Guna Lahan (Studi Kasus : Koridor 2 Trans Mamminasata)". Jurnal Ilmiah Gema Aktualita, Vol. 5 No. 2, Desember 2016. Universitas Pelita Harapan. Surabaya.

Upa, Verdy Ananda (2017). "Perhitungan Jumlah Permintaan Potensial Bus Rapid Transit (BRT) Mamminasata Koridor 1 dengan menggunakan Special Conventional Transport Model". Tesis Magister. Jurusan Teknik Sipil. Institut Teknologi Sepuluh Nopember (ITS). Surabaya.

Upa, Verdy Ananda \& Setyadi, Rahmat (2018). "Analisis Perpindahan Pengguna Moda Angkutan Umum (Lyn JSP) ke Moda Komuter Supor (Surabaya-Porong) dengan Menggunakan Metode Logit Biner Selisih Waktu dan Biaya". Jurnal Ilmiah Gema Aktualita, Vol. 7 No. 1, Juni 2018, pp : 10-15. Universitas Pelita Harapan. Surabaya. 
(e)ISSN 2615-1847 (p)ISSN 2615-1839

Jurnal Manajemen Aset Infrastruktur \& Fasilitas - Vol. 2, No. 2, September 2018 